\title{
An Analysis of the Effects of Seismic Events on The Turkish Stock Market ${ }^{1}$
}

\section{Tuna Can GÜLEÇ iD a}

a Manisa Celal Bayar Üniversitesi Uygulamalı Bilimler Fakültesi Bankacilik ve Finans Bölümü, Manisa, Turkey. tunacan.gulec@cbu.edu.tr

\begin{tabular}{|c|c|}
\hline ARTICLE INFO & ABSTRACT \\
\hline $\begin{array}{l}\text { Received } 4 \text { October } 2020 \\
\text { Revised } 8 \text { December } 2020 \\
\text { Accepted } 15 \text { December } 2020\end{array}$ & $\begin{array}{l}\text { Purpose - This study aims to elaborate on the mechanisms of interaction between seismic events } \\
\text { and the Turkish stock markets. } \\
\text { Design/methodology/approach - To model this relationship, the properties of earthquakes has been } \\
\text { modeled using Mw and ML parameters. Earthquakes' distance to the surface and the distance to the } \\
\text { closest city center are also added as independent variables. Dataset consists of } 7333 \text { observations of } \\
\text { daily frequency between } 01.01 .2000-28.01 .2020 \text { covering longer than a } 20 \text {-year period. The index of } \\
\text { BIST TUM is used to represent the response of the Turkish stock market. Preliminary analysis on the } \\
\text { dataset suggested a threshold effect and therefore, the threshold VAR model has been used to model } \\
\text { the series. } \\
\text { Findings - Findings validate the existence of a significant threshold effect at } 4.3 \text { magnitude, which } \\
\text { points out to the conclusion that earthquakes below a certain magnitude do not have a significant } \\
\text { relationship with the stock markets in Turkey. Additionally, as seismic events occur closer to the } \\
\text { surface, their negative effects on the market seem to amplify. This effect is also observed as seismic } \\
\text { events get closer to city centers. Additionally, non-damaging seismic events seem to cause } \\
\text { substantial market responses. } \\
\text { Discussion - The effects of nondestructive earthquakes along with the effects of aftershocks } \\
\text { following a destructive earthquake indicate that the financial consequences of earthquakes in Turkey } \\
\text { are likely to be more related to the perception of risk, rather than the actual destructiveness of the } \\
\text { earthquake. Findings also indicate that the aftershocks following a big earthquake hasten the } \\
\text { recovery of the BIST TUM index. }\end{array}$ \\
\hline
\end{tabular}

\section{INTRODUCTION}

With 485 active fault lines covering approximately $84 \%$ of its surface area, Turkey is one of the most seismic event-vulnerable countries in the world (Emre et al., 2018). While the losses that seismic events cause in terms of human lives cannot be measured, seismic event's economic and financial effects are a widely studied subject of research. Historically, the region of Anatolia has been struck by devastating seismic events for thousands of years. Another critical factor for turkey is that its population is concentrated in cities that are most prone to seismic events. Istanbul is the worst example of this. With a population of fourteen million approximately half of Turkey's GDP is indirectly or directly connected to firms and institutions in Istanbul.

The initial damage caused by the seismic events, however, is only a portion of their destructive effects. These disasters are usually followed by the economic and financial spillover effects that cause extensive turmoil both domestically and globally. In this study, in order to understand the nature of the relationship between seismic events and financial markets, I have created a set of models to test the effects of different variables on the Turkish stock exchange.

A significant portion of the studies in the literature fails to find a relationship between seismic events and stock market volatility. Taking a closer look at these studies it can be seen that they include all seismic events without specifying a threshold value. There are days that dozens of seismic events occur without anyone feeling anything or any media attention is given. Therefore, in this study, I first determine a threshold value

\footnotetext{
${ }^{1}$ The preliminary abstract of this research was discussed at the International Congress of Economics and Business ICEB 2019 under the title of "The Financial Consequences of Earthquakes on the Stock Markets and Economic Indicators".
}

\section{Önerilen Atıf/ Suggested Citation}

Güleç, C., T. (2020). An Analysis of the Effects of Seismic Events on The Turkish Stock Market, Journal of Business Research-Turk, 12 (4), 4043-4050. 
for seismic events that have an impact on the market. In the measurement of the magnitude of seismic events, the Richter scale(ML) is used where available. If Richter scale measurement is not available, then the Moment magnitude $(\mathrm{Mw})$ is used. If a series of seismic events above the threshold occurred during the same day, then the one with the highest magnitude is accounted as magnitude and the following events are considered as Aftershocks. Methodologically, I observe the effects of not only the magnitude of the earthquake but also its proximity to cities and distance to the surface.

\section{LITERATURE}

Literature is reviewed under two main categories. The first being the studies that analyze the effects of individual seismic events and their aftermaths and the second being the studies that analyze the generalized effects of seismic events and disaster's at a macro-level.

A study that evaluates the 1906 San Francisco earthquake, discusses the economic and financial aftershocks of the earthquake (Odell \& Weidenmier, 2004). The study claims that earthquakes in open economies have globewide effects due to large amounts of cash inflows following the earthquake in terms of insurance policy payments. The study also discusses that these insurance payments may even have resulted in overall benefit for the American economy if there wasn't economic discrimination from the bank of England imposed on American markets.

In a study, October 17, 1989, the California earthquake's effects on the stock prices of the real estate industry have been examined (R. Shelor et al., 1990). The finding of the study indicates that stock prices of the real estate firms located in California area have remained unaffected by the shock of the earthquake while real estate firm located in San Francisco area was negatively affected. Another study analyzing this earthquake event focuses on the loss of payments to the insurers (R. M. Shelor et al., 1992). Study tests two opposing hypotheses. The first hypothesis is that the depletion of surplus accounts during earthquakes causes investors to cut back from insurance expenditures, resulting in a reduced payment of insurance primes. The second hypothesis holds that such catastrophic events cause insurers an increased benefit by increased demand. The results of the study support the latter hypothesis. For the same earthquake in Loma Prieta, the stock prices of the insurance companies have been examined by another study (Aiuppa et al., 1993). The study tests three hypotheses, first being the cash outflows, second, being the abandonment of soft-market pricing, and last being the increased cash flows due to the increased risk premiums of earthquake insurances. Using a two-index market model, the finding of the study indicates that earthquakes increase the earnings of earthquake insurers.

The other highly studies earthquake event in the literature is the 2011 Japanese earthquake and its following tsunami and nuclear crisis. To investigate contagion effects that occurred in the Japanese earthquake and its subsequent events, a study analyzes heteroscedasticity biases based on correlation coefficients to determine the existence and the pattern of a potential contagion (Asongu, 2012). The study uses a 12-month preearthquake period and a 2-month post-earthquake period for 33 international exchange rates and stock market indices. The findings of the study indicate the existence of contagion in the stock markets of Bahrain, Saudi Arabia, South Africa, and Taiwan. A book that evaluates the economic destruction caused by this earthquake reports extensive macroeconomic figures regarding this event that are in line with the findings of this study (Nanto, 2011).

The studies that aren't based on any specific event evaluate the event of earthquakes on a macroeconomic basis. While not directly focusing on the earthquakes, a study on the effects of extreme events tests the validity of the efficient market hypothesis based on the effects of unexpected events that occurred in the Turkish markets (Aktas \& Oncu, 2006). The results of the study support the hypothesis that extreme events affect the stock market. Another study on the macroeconomic consequences of the disasters including earthquakes tests the hypothesis that economically developed countries suffer significantly less destructive consequences compared to developing countries, especially in the long run (Noy, 2009). Findings of the study indicate that countries with higher literacy rates, higher per capita income, and a higher degree of openness to trade along with higher levels of government spending are much more durable to shocks caused by disasters. Additionally, the study finds that fewer spillover effects are caused by disasters that took place in developed countries compared to the developing countries. Another study on the macroeconomic effects of earthquakes on the stock markets examines the effects of major earthquakes on the returns and the volatility of aggregate stock market indices (Ferreira \& Karali, 2015). The study uses a data set covering thirty-five financial markets 
T. C. Güleç 12/4 (2020) 4043-4050

for twenty years. The results of the study indicate that financial markets are resilient to earthquakes. The study also finds evidence that stock market volatility and returns remain unaffected by the earthquakes. The findings of this study may be misleading because the data set includes earthquakes of any magnitude. In order to repeat the same mistake, we took a threshold value for the magnitude of earthquakes to be considered a destructive earthquake as explained in the introduction section.

Further discussion of the literature against similar up-to-date studies will take place by comparison in the conclusion section based upon the findings of the study.

\section{DATA AND RESEARCH METHODS}

The data set consists of 7333 daily observations between 01.01 .2000 and 28.01.2020. Metrics regarding seismic events are acquired from the public database of the Kandilli Observatory and earthquake research institute. Borsa İstanbul Index data(XUTUM) is acquired from the FINNET database. The variables used in the study are bisttum, magnitude, aftershock, distancetocenter, and distancetosurface. Explanations of the variables used in the analysis can be found in Table 1.

Table 1. Descriptions of Variables

\begin{tabular}{|l|l|}
\hline bisttum & Borsa Istanbul Tum Index \\
\hline magnitude & The magnitude of the biggest seismic event in the given date \\
\hline aftershock & $\begin{array}{l}\text { The number of seismic events on the given date, following the greatest seismic } \\
\text { event. }\end{array}$ \\
\hline distancetocenter & $\begin{array}{l}\text { Distance between the center of the seismic event and the center of the nearest } \\
\text { city. As a percentage of maximum distance. }\end{array}$ \\
\hline distancetosurface & $\begin{array}{l}\text { The distance of the center of the seismic event to the surface. As a percentage of } \\
\text { maximum distance. }\end{array}$ \\
\hline
\end{tabular}

Seismic events that are closer to residential areas are perceived as significantly more influential than the ones that take place in the rural areas. "distancetocenter" Variable is used to represent the distance of seismic events to the nearest city. In order to calculate this variable, the coordinates of all cities within Turkey are acquired using google earth. This data was presented as a four-value array in form of ' $x_{1} y_{1} x_{2} y_{2}{ }^{\prime}$. This array represents the rectangle of borders that are tangent to the maximal borderlines of each city. In the first step of data preparation, the following model is used to calculate the center of the city:

$$
\frac{y_{2}-y_{1}}{2}+y_{1}
$$

In this equation, the latitude of the central point is found.

$\frac{x_{2}-x_{1}}{2}+x_{1}$

And in this equation similarly, the longitude of the central point is found. In Figure 1, these points are represented as $x_{c} y_{c}$ point. 


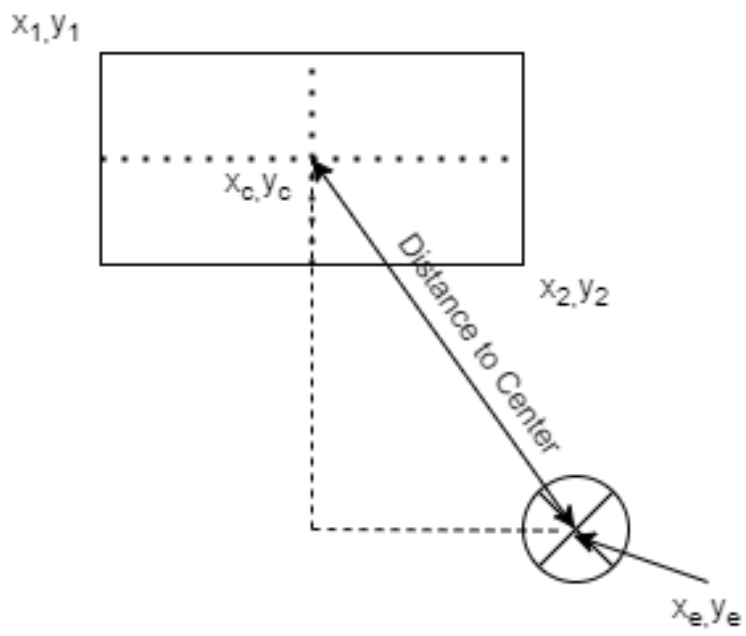

Figure 1. Calculation of Distance Variables

The longitude and latitude of the center of seismic events are represented in Figure 1 as $x_{e} y_{e}$. Following this, the distance to the center is calculated using the Pythagorean theorem.

$$
\left(x_{c}-x_{e}\right)^{2}+\left(y_{c}-y_{e}\right)^{2}=\text { Distance to Center }
$$

Following this, the distance to the center is scaled over its maximum value to normalize the effects of rural seismic events as in the following model.

"distancetocenter" $=\frac{\text { Distance }_{n}}{\text { Distance }_{\text {Max }}}$

In order to be able to use the Threshold VAR model, C(d) non-linearity test created by Tsay(1998) has been used. The results of the non-linearity test are reported in Table 2.

Table 2. Non-Linearity Test Results

\begin{tabular}{|l|l|l|l|}
\hline$d$ & $m 0$ & $C(d)$ & Olasilık Değeri \\
\hline 1 & 50 & 389.35 & 0.0000 \\
\hline 1 & 100 & 388.14 & 0.0000 \\
\hline 2 & 50 & 155.97 & 0.0000 \\
\hline 2 & 100 & 153.90 & 0.0000 \\
\hline 3 & 50 & 75.25 & 0.0362 \\
\hline 3 & 100 & 78.82 & 0.0193 \\
\hline 4 & 50 & 106.57 & 0.0000 \\
\hline 4 & 100 & 109.01 & 0.0000 \\
\hline 5 & 50 & 89.92 & 0.0020 \\
\hline 5 & 100 & 91.23 & 0.0015 \\
\hline 6 & 50 & 94.47 & 0.0007 \\
\hline 6 & 100 & 93.87 & 0.0008 \\
\hline $\mathrm{y}=4.3 \quad \mathrm{AIC}=-37249.5$ & & & \\
\hline
\end{tabular}

$\mathrm{C}(\mathrm{d})$ test has been conducted with " $\mathrm{d}=1$ to 6 ", and using " $\mathrm{m} 0=25$ and 50 " starting points. In line with the results of the test, the delay parameter has been selected as 1 where the chi-square value is maximized. Since where $\mathrm{d}=1$, the chi-square value is 389.35 with the prob value of 0.000 , the null hypothesis is rejected and TVAR can be considered a valid model for the series.

The magnitude series is selected as the threshold variable for the TVAR model. In other words, it is assumed that the BIST TUM index will react differently based on the magnitude of the seismic event. As can be seen in the non-Linearity test results in Table 2, the threshold magnitude $(\gamma)$ is reported to be 4.3 . In this model, regime 
T. C. Güleç 12/4 (2020) 4043-4050

1 represents situations where the seismic event is below the threshold, and regime 2 represent situations where the magnitude of the seismic event is above the stated threshold. Our hypothesis focuses only on regime 2.

With the validity of the TVAR model confirmed, the BIST TUM index's impulse-response functions are drawn. Impulse-response functions represent the BIST TUM index's response to 1 standard deviation of shock in the respective variable. Impulse-response functions are demonstrated in the following figures. According to the non-linearity test results in Table 2., 1 standard deviation of shock in the magnitude, aftershock count(aftershock), the distance of seismic event to the surface(distancetosurface), and distance of seismic event to the nearest city center(distancetocenter), all have statistically significant and negative effects on the BIST TUM index that persists for 2 days. The model divides the events under High-VAR and Low-VAR regimes at the threshold of 4.3. As the High-VAR regime is the focus of this study, we evaluate the effect during that regime.

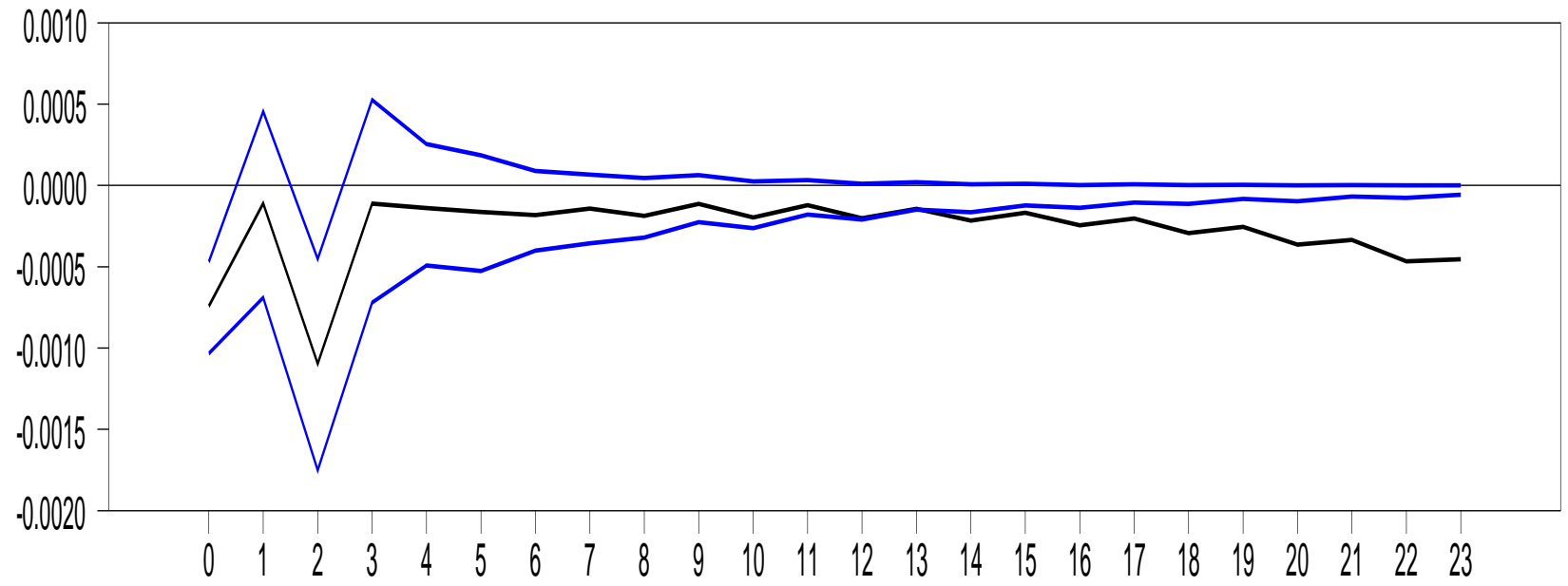

Figure 2. The Response of BIST TUM Index to Magnitude (>4.3)

As can be seen in Figure 2, Magnitude has a negative effect on the index returns that is significant during the second day following the seismic event.

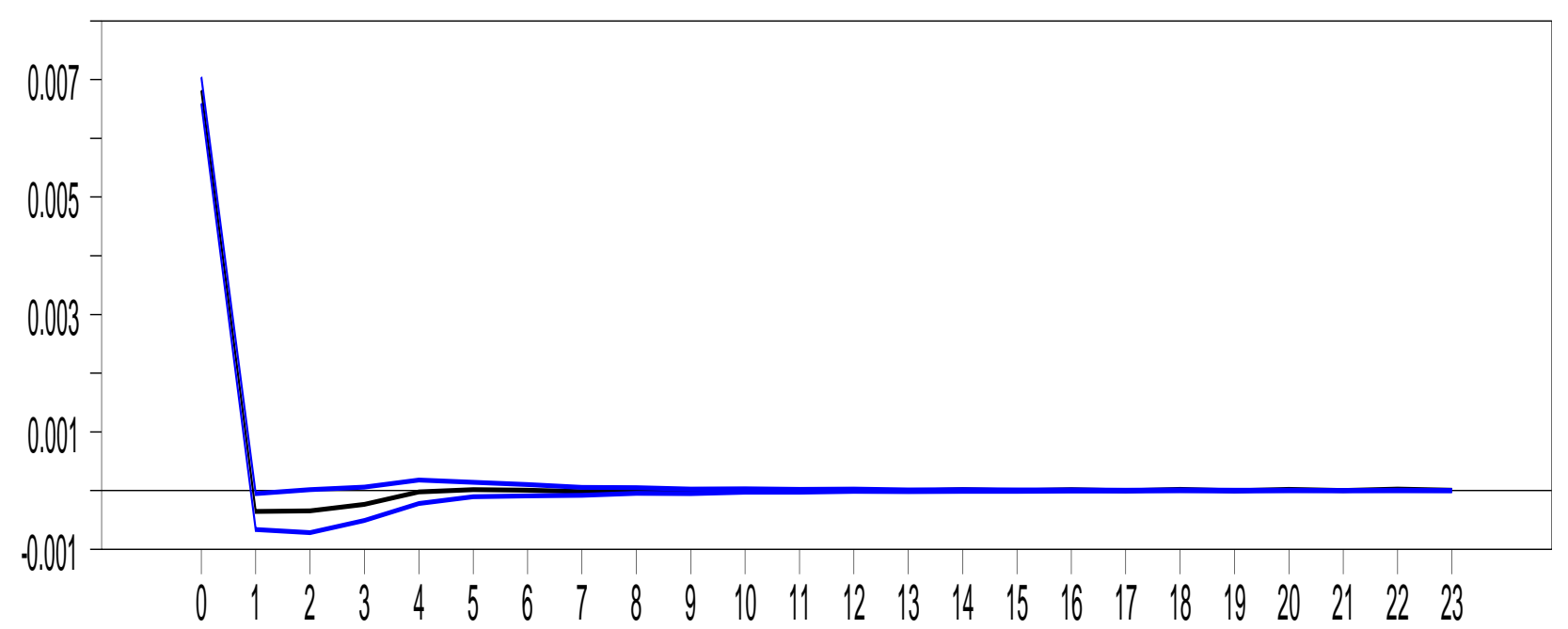

Figure 3. Response of BIST TUM Index to Aftershocks ( $>4.3)$

Aftershocks as demonstrated in Figure 3, that are classified in this study as the seismic events that take place on the same day following the biggest seismic event, create a short-term positive effect on the market. 


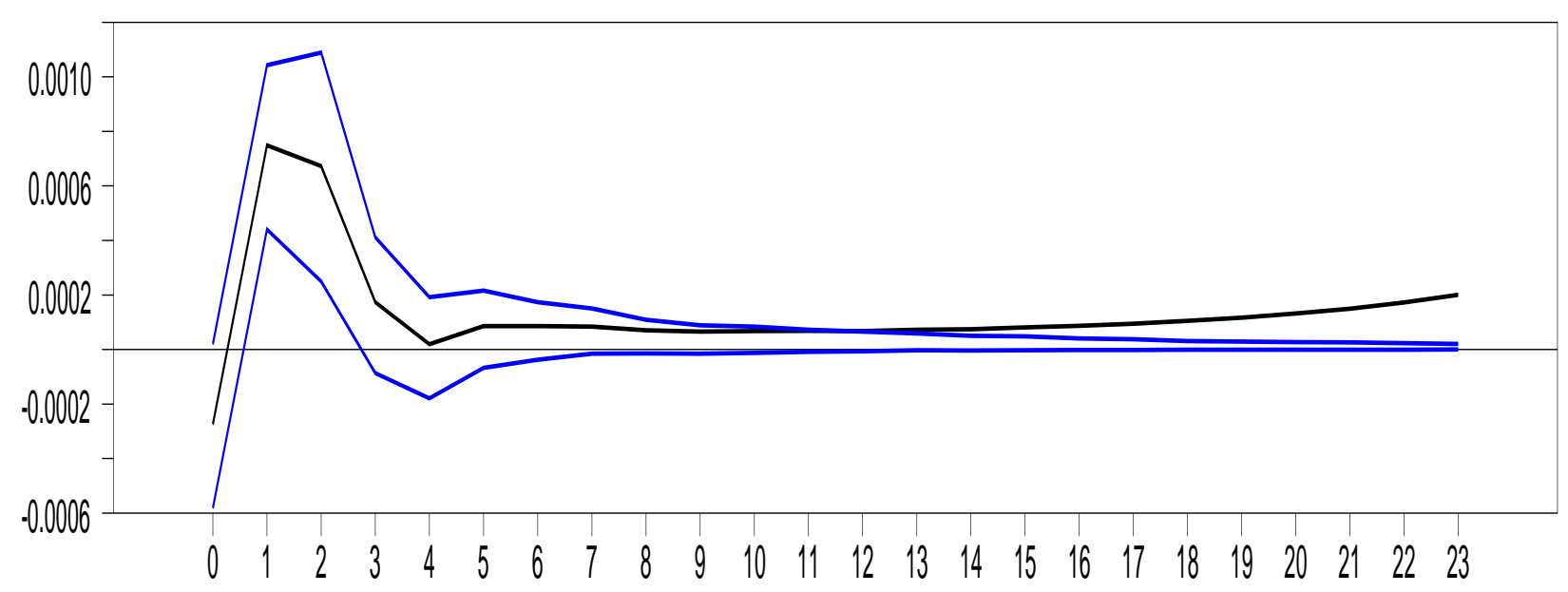

Figure 4. Response of BIST TUM Index to Distance to Center ( $>4.3)$

Distance to the nearest city center has a positive relationship with the index returns as demonstrated in Figure 4 , these effects last for the following 2 days.

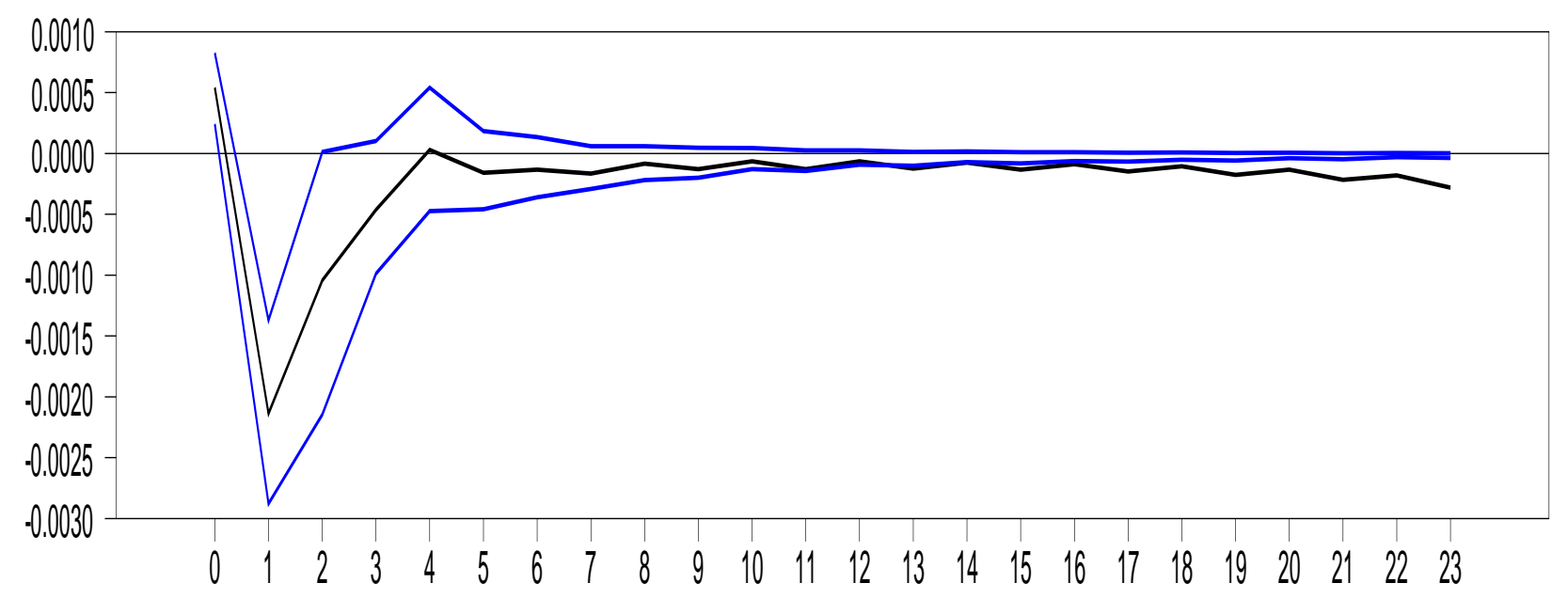

Figure 5. Response of BIST TUM Index to Distance to Surface (>4.3)

Distance to the surface is significant in the same manner as magnitude, as seen in Figure 5, creating an inverse effect of index return for 3 days.

These findings will be discussed collectively in the conclusion section.

\section{CONCLUSION}

Findings indicate that seismic events below 4.3 magnitudes have no significant effect on the stock market of Turkey, Seismic events above a magnitude of 4.3 have a significant and negative effect on the market. For earthquakes above 4.3 magnitudes, aftershocks start to become significant as well, comparatively, singular shocks have a greater negative impact on the market than shocks that's are followed by several aftershocks. The distance of the earthquake to the surface is another indicator of its influence on the markets and results indicate that earthquakes that are closer to the surface cut the index returns by a higher margin than the ones that take place in deeper places. The Influence of the distance between the epicenter of the earthquake and the nearest city center is also a very significant relationship. An earthquake that takes place in the center of a densely populated city and one that occurs in the remote mountain ranges will create significantly different effects on the markets. Results are in line with this and as can be seen in Figure 4, there is a clear positive relationship between the BIST TUM index and the distance variable. In other words, as earthquakes take place in further away locations than the city center, BIST TUM index returns are positively affected, in contrast to closer ones. While these results are in line with common logic, a comparison of results with similar studies is made. Table 3 demonstrates the comparison of our results with the rest of the literature. 
T. C. Güleç 12/4 (2020) 4043-4050

Table 3. Result Comparison with the Literature

\begin{tabular}{|c|c|c|c|}
\hline Author (date) & Country & $\begin{array}{l}\text { Interaction } \\
\text { with Study }\end{array}$ & Focal Point \\
\hline (Aiuppa et al., 1993) & United States & Complementary & $\begin{array}{l}\text { Insured assets are perceived as better-off after seismic } \\
\text { events }\end{array}$ \\
\hline (Asongu, 2012) & $\begin{array}{l}33 \text { Stock } \\
\text { Markets }\end{array}$ & Complementary & $\begin{array}{l}\text { There is little-to-none international contagion effect in } \\
\text { the } 2011 \text { Japan Earthquake }\end{array}$ \\
\hline (Liwei, 2011) & China & Complementary & $\begin{array}{l}\text { Negative investor sentiment persists long after the } \\
\text { seismic event }\end{array}$ \\
\hline (Luo, 2012) & $\begin{array}{l}6 \text { Stock } \\
\text { Markets }\end{array}$ & Complementary & $\begin{array}{l}\text { The international impact of local events is comparably } \\
\text { insignificant. }\end{array}$ \\
\hline (R. M. Shelor et al., 1992) & United States & Complementary & Insurance companies are better off in the mid-term. \\
\hline (Ferreira \& Karali, 2015) & Multi-Event & Contradictory & $\begin{array}{l}\text { Study indicates that the stock market volatility is mostly } \\
\text { unaffected by earthquakes }\end{array}$ \\
\hline (Bolak \& Süer, 2008) & Turkey & In Line & Abnormal results are found even in the insurance sector. \\
\hline (Doan et al., 2011) & Japan & In-Line & $\begin{array}{l}\text { Social media interactions can be used as a volatility } \\
\text { indicator. }\end{array}$ \\
\hline (Hood et al., 2013) & Japan & In-Line & $\begin{array}{l}\text { Short-term extreme volatility following the seismic } \\
\text { event. }\end{array}$ \\
\hline (Shan \& Gong, 2012) & China & In-line & $\begin{array}{l}\text { Firms closer to the epicenter are significantly more } \\
\text { affected. }\end{array}$ \\
\hline (Takao et al., 2013) & Japan & In-Line & $\begin{array}{l}\text { Earthquake insurance system's stabilizing effect of } \\
\text { Stock Markets. }\end{array}$ \\
\hline (Wang et al., 2012) & Japan & In-Line & $\begin{array}{l}\text { Abnormal behavior was observed across } 11 \text { Stock } \\
\text { exchanges. }\end{array}$ \\
\hline (Tao et al., 2019) & Japan & Mixed & $\begin{array}{l}\text { Detects abnormal market behavior for up to } 10 \text { days, } \\
\text { excluding the construction sector. }\end{array}$ \\
\hline (Valizadeh et al., 2017) & $\begin{array}{l}19 \text { Stock } \\
\text { Markets }\end{array}$ & Mixed & $\begin{array}{l}\text { Similar to (Tao et al., 2019), the study finds a list of } \\
\text { sectors that benefit from the earthquake. }\end{array}$ \\
\hline
\end{tabular}

The results of the study are largely in line with the rest of the literature. Only a single study in the literature that contradicts our findings could be found, which states that the earthquakes have no effect on stock market volatility. Overall, the response of the stock market to seismic events is temporary and quickly dissipates in a short matter of time. However, as the relationship is exponential and the number of seismic events above 7.0 magnitude in the dataset is only a handful, the results of a catastrophic seismic event cannot be forecasted with this model. This model can be improved by adding more variables into the equation such as changes in macroeconomic variables and the regional GDP of the regions affected by the seismic event. The scarcity of extreme observations can be overcome by adding more countries to the dataset for longer periods. In further studies, the addition of such variables may result in a more accurate characterization of the financial impacts of seismic events.

Collectively, the findings create the impression that the BIST TUM index is affected by the nondestructive earthquakes. This effect is amplified as the earthquake is felt by more people, even if it is categorized as nondestructive. 


\section{T. C. Güleç 12/4 (2020) 4043-4050}

\section{REFERENCES}

Aiuppa, T. A., Carney, R. J., \& Krueger, T. M. (1993). An examination of insurance stock prices following the 1989 Loma Prieta Earthquake. Journal of Insurance Issues, 1-14.

Aktas, H., \& Oncu, S. (2006). The stock market reaction to extreme events: The evidence from Turkey. International Research Journal of Finance and Economics, 6(6), 78-85.

Asongu, S. A. (2012). The 2011 Japanese earthquake, tsunami and nuclear crisis: Evidence of contagion from international financial markets. Journal of Financial Economic Policy, 4(4), 340-353.

Bolak, M., \& Süer, Ö. (2008). The effect of Marmara earthquake on financial institutions.

Doan, S., Vo, B.-K. H., \& Collier, N. (2011). An analysis of Twitter messages in the 2011 Tohoku Earthquake. 58-66.

Emre, Ö., Duman, T. Y., Özalp, S., Şaroğlu, F., Olgun, Ş., Elmacı, H., \& Can, T. (2018). Active fault database of Turkey. Bulletin of Earthquake Engineering, 16(8), 3229-3275.

Ferreira, S., \& Karali, B. (2015). Do earthquakes shake stock markets? PloS One, 10(7), e0133319.

Hood, M., Kamesaka, A., Nofsinger, J., \& Tamura, T. (2013). Investor response to a natural disaster: Evidence from Japan's 2011 earthquake. Pacific-Basin Finance Journal, 25, 240-252.

Liwei, S. (2011). Psychological or Real? The Effect of the Wenchuan Earthquake on China's Stock Market [J]. Economic Research Journal, 4.

Luo, N. (2012). The impact of natural disasters on global stock market: The case of the Japanese 2011 Earthquake.

Nanto, D. K. (2011). Japanis 2011 Earthquake and Tsunami: Economic Effects and Implications for the United States. DIANE Publishing.

Noy, I. (2009). The macroeconomic consequences of disasters. Journal of Development Economics, 88(2), 221-231.

Odell, K. A., \& Weidenmier, M. D. (2004). Real shock, monetary aftershock: The 1906 San Francisco earthquake and the panic of 1907. The Journal of Economic History, 64(4), 1002-1027.

Shan, L., \& Gong, S. X. (2012). Investor sentiment and stock returns: Wenchuan Earthquake. Finance Research Letters, 9(1), 36-47.

Shelor, R., Anderson, D., \& Cross, M. (1990). The impact of the California earthquake on real estate firms' stock value. Journal of Real Estate Research, 5(3), 335-340.

Shelor, R. M., Anderson, D. C., \& Cross, M. L. (1992). Gaining from loss: Property-liability insurer stock values in the aftermath of the 1989 California earthquake. Journal of Risk and Insurance, 476-488.

Takao, A., Yoshizawa, T., Hsu, S., \& Yamasaki, T. (2013). The effect of the Great East Japan earthquake on the stock prices of non-life insurance companies. The Geneva Papers on Risk and Insurance-Issues and Practice, 38(3), 449-468.

Tao, Z., Han, L., Song, Y., \& Bai, K. (2019). Stock market reactions to the 2011 off the Pacific Coast of Tohoku Earthquake. International Journal of Disaster Risk Reduction, 41, 101294.

Tsay, R. S. (1998). Testing and modeling multivariate threshold models. Journal of the American Statistical Association, 93(443), 1188-1202.

Valizadeh, P., Karali, B., \& Ferreira, S. (2017). Ripple effects of the 2011 Japan earthquake on international stock markets. Research in International Business and Finance, 41, 556-576.

Wang, X., Bai, Y., \& Wang, L. (2012). The influence of japanese earthquake on global stock markets. 259-262. 